\title{
DIALÓGICA DA COLONIZAÇÃO CULTURA E PERFOMANCE NAS LETRAS E NAS VOZES DE ANCHIETA E VIEIRA
}

Augusto Rodrigues da Silva Junior (UnB)

Na performance do sacramento de Anchieta e Vieira revela-se uma dialógica da colonização. A cultura popular é revisitada nos rituais que congregam autores, atores $e$ espectadores. Aliando literatura e performance, reavaliase esse período dialogando com o efêmero da oralidade (Zumthor), a liminaridade (Turner) e o catolicismo carnavalizado (Bakhtin) em solo luso-brasileiro.

PERFORMANCE, ANCHIETA, VIEIRA, DIALÓGICA DA COLONIZAÇÃO, CATOLICISMO CARNAVALIZADO.

SILVA JUNIOR, Augusto Rodrigues da. Dialógica da colonização: cultura e performance nas letras e nas vozes de Anchieta e Vieira. Textos escolhidos de cultura e arte populares, Rio de Janeiro, v.8, n.1, p. 7-20, mai. 2011. 
A performance é uma espécie de fronteira que permite vislumbrar as mais diversas representações e linguagens. As marcas do sujeito e de seu outro estão impressas no espaço público, palco de possibilidades e de novas formas para se pensar a literatura e a história cultural. Os estudos híbridos apresentam-se como campo científico e artístico, fronteiriço e 'indirecionado', que auxiliam na reflexão dialógica sobre as formas contemporâneas do pensamento artístico.

Nesse sentido, uma vez que essa ferramenta analítica permite aproximar campos, abre-se também a possibilidade de olhar para a historiografia literária renovando o cânone e o entendimento de clássicos. Diante dessa emergência performática como caminho para o conhecimento, novos vínculos se estabelecem, e outros interesses surgem. Com isso, percebe-se que comunidades heterogêneas e multifacetadas estabelecem diálogos a partir de diferentes sistemas 'intersemióticos', e, de forma consciente ou não, vários suportes e múltiplas formas discursivas convidam à intervenção, à 're-investigação' do mesmo.

A performance atende às necessidades de uma humanidade acostumada a viver no "pós": pós-romantismo, pós-guerra, pós-modernidade... Nesse ambiente de posteridade presentificada, pretende-se analisar o período da colonização brasileira. Um 'grande barroco' dos primeiros séculos de dominação/habitação lusitana em solo brasileiro. Congregando uma visada dialógica, a partir de manifestações do contexto católico-carnavalizado, serão analisados os escritos fronteiriços dos padres Anchieta e Vieira.

Para tal, antes da análise propriamente dita, será necessário problematizar os estudos da performance e o que eles podem iluminar no campo literário. Posteriormente, de maneira mais específica, colher do chão colonial as fronteiras do literário e do espetáculo, cultuadas e cultivadas no cotidiano do catolicismo carnavalizado luso-brasileiro. Ainda que breve, a diegese do campo da performance cultural se faz necessária para, em seguida, concretizar a análise e revisão das letras e vozes coloniais.

Sem perder a consciência estética, salientada por Candido (1993), nos momentos de formação da literatura brasileira, propõem-se contornos diferentes a partir da relação entre a letra, a voz e o corpo:

evocaremos a oralidade natural de suas culturas: como um conjunto complexo e heterogêneo de condutas e de modalidades discursivas comuns, determinando um sistema de representações e uma faculdade de todos os membros do corpo social de produzir certos signos, de identificá-los e de interpretá-los da mesma maneira; como (...) um fator entre outros de unificação das atividades individuais (ZUMTHOR, 2001, p. 22).

Assim, da consciência de uma prática artística, dotada de sentido histórico, desvela-se a necessidade de analisar uma 'língua geral', cotidiana e pública, que se estabeleceu na fundação e continuidade de uma civilização. De forma muito genérica, o que este artigo propõe é uma revisão da expressão literária colonial, como Bakhtin e Zumthor fizeram com a literatura medieval europeia em seus estudos. 
Dessa perspectiva, apreende-se que as expressões coloniais, pessoais e coletivas, enformam uma pluralidade de ideias e desvelam a incorporação de novas características aos gêneros tradicionais europeus. A noção de performance, arraigada às imagens da voz, do corpo e das letras coloniais, amplia os ecos dos discursos nos primeiros séculos no Brasil. Isso significa dizer que, em vez de priorizar o escrito, a produção tipográfica e uma aparente organização (autor-obra-público), este estudo pressupõe a oralidade. Uma corporificação que precede a escrita, ou que a ela se liga no instante de fala, no horizonte de observação do objetivo performático (ZUMTHoR, 2001, p. 109).

Com a contribuição analítica de Mikhail Bakhtin e a aproximação da visão da performance cultural de Victor Turner, renova-se o pensamento sobre as letras coloniais. Mais especificamente, literatura e cultura promovem o contato dialógico e a análise de ações sociais e artísticas, adquirindo formas por meio de metáforas e performances.

A estrutura processual para a análise desse período pressupõe os acontecimentos no "vão entre mundos ordenados" - betwixt and between. Segundo Turner, a estrutura de uma ação social pode ser mais bem apreendida em situações fronteiriças: campos simbólicos em sociedades tribais, ritos de iniciação prolongados e nos "'gêneros liminoides' - a literatura, o cinema e o jornalismo que subvertem axiomas e padrões" (TURNER, 2008, p. 12).

Mikhail Bakhtin, de modo semelhante, também foi um admirador do limen: Nesse processo de iluminação recíproca das línguas, a época contemporânea viva representa tudo que é novo, que não existia antes, as novas coisas, noções, opiniões, ela atinge uma tomada de consciência de excepcional acuidade; as fronteiras dos tempos, as fronteiras das épocas, das concepções do mundo, do cotidiano são distintamente tateadas (BAKHTIN, 2002, p. 412. Grifos meus).

A partir de seus estudos sobre cultura popular, o pensador russo provoca uma revisão na história da literatura ocidental. No campo de iluminação recíproca de culturas e línguas, constrói uma visada que pressupõe 'inacabamentos': fronteiras que não demarcam, mas ampliam o espaço a ser percorrido. Nessa abordagem do discursivo, do popular, das manifestações oficiais (documentadas por portadores individuais da escrita) pressupõe-se a instabilidade, o rasgo na ordem, o imprevisível do cotidiano.

Desses pressupostos, irrompe esse novo horizonte colonial como confronto de diferenças e passa a ser entendido como um momento detentor de lutas (ainda que violentas) entre mentalidades. De um conjunto de vozes e de 'respondibilidades' entre discursos coletados e estilizados, carregados de condutas, modalidades e inovações comungadas no instante de seu acontecimento, a perspectiva bakhtiniana torna-se o cerne condutor nessa relação entre literatura e performance. De suas análises reformulam-se concepções estéticas e ideológicas que revelam uma capacidade de "desfazer-se de muitas exigências do gosto literário profundamente arraigadas" (BAKHTIN, 2002, p. 3) aos padrões racionalistas e formalistas. As categorias propostas por ele evocam a 'multiformi- 
dade' e a heterogeneidade, e deixam reverberar aspectos corporais, cotidianos, liminares e festivos:

1. As formas dos ritos e espetáculos (festejos carnavalescos, obras cômicas representadas nas praças públicas etc.);

2. Obras cômicas verbais (inclusive as paródicas) de diversa natureza: orais e escritas, em latim ou em língua vulgar;

3. Diversas formas e gêneros do vocabulário familiar e grosseiro (insultos, juramentos, blasões populares etc.) (BAKHTIN, 2002, p. 4).

Sua noção de carnavalização amplia o entendimento do literário. Embora não tratasse da ideia de performance, sua análise de Gargantua e Pantagruel aproxima-se fortemente desse campo cultural. Afinal, ele mapeia ritos e espetáculos, elementos verbais e orais, modalidades do vocabulário familiar e modos de ser e estar na sociedade no contexto de François Rabelais.

Dessa perspectiva, principalmente pelas grandes mudanças no processo de colonização, podem-se pensar as primeiras manifestações coloniais luso-brasileiras como expressões dotadas de elementos performáticos e de espetacularidade. Dentro das dimensões do processo de povoamento e de aculturação, as marcas do teatro litúrgico medieval (PICCHIO, 1964, p. 31), betwixt and between, serão traçadas nas tradições orais populares e nas variantes católicas que aportaram no Brasil.

Nas festas religiosas que contavam com o teatro de Anchieta e, em datas festivas, com os sermões de Vieira pode-se falar em uma performance litúrgica no contexto de um barroco carnavalizado. Nessas manifestações corporais e orais tem-se muito da esfera cotidiana e do catolicismo festivo, funcionando sempre como renovação universal e liminar:

Por seu caráter concreto e sensível e graças a um poderoso elemento de jogo, elas [as festas] estão mais relacionadas às formas artísticas e animadas por imagens, ou seja, às formas do espetáculo teatral. E é verdade que as formas do espetáculo teatral na Idade Média se aproximavam na essência dos carnavais populares, dos quais constituíam-se até certo ponto uma parte. No entanto, o núcleo dessa cultura, isto é, o carnaval, não é de maneira alguma a forma puramente artística do espetáculo teatral e, de forma geral, não entra no domínio da arte. Ele se situa nas fronteiras entre a arte e a vida. Na realidade, é a própria vida apresentada com os elementos característicos da representação (BAKHTIN, 2002, p. 6. Grifos meus).

Nesse ambiente festivo, erige-se um teatro de vícios e moralidades. Trata-se então, de um ambiente católico-carnavalizado mobilizando as fronteiras entre a arte e a vida. Um processo dialógico da colonização configurado com os topoi lusitano-ocidentais que aportaram na América e que ofereceram o registro dessa expressão liminar, em consonância, por sua vez, com os discursos e revisões (nada paradisíacas) que forjaram padrões estéticos e éticos ligados ao comportamento, à organização social, ao contexto político-religioso. Indo além da experiência e da fantasia, nos discursos em questão pode-se pensar esse processo como o momento de "formação de grandes espaços político-territoriais" marcados pelo choque de culturas e pela fundação de novos centros da vida polí- 
tica e econômica que buscaram "afirmação e expansão na prática do mercantilismo e na formação de impérios coloniais" (PALACIN, 1981, p. 13).

No Brasil tivemos espetáculos teatrais e performáticos desde o princípio. Na liturgia católica da primeira missa, carregada de símbolos e dramas sociais, instaura-se o choque de mentalidades em um espaço indefinido, desconhecido, dividido entre portugueses e espanhóis. Daí a insistência em denominar fronteiriços esses momentos iniciais, carregados de sentidos e plenos de campos e metáforas.

Nesse universo de dominação linguística, padres e soldados combinam a literatura culta clássica com gêneros litúrgicos medievais. O humanismo renascentista é penetrado por tradições populares ibéricas (PICCHIO, 1964, p. 26-32), presentes nos autos teatrais, nas construções líricas e na herança retórica, reinventada em autos e sermões. Além disso, a reverberação, no palco dos acontecimentos, convocava novas formas de expressão, completamente reinventadas, dada a necessidade de alcance expressivo, religioso, econômico. É nesse contexto que a velha Idade Média reinventa seu barroco em outro solo. O pecado e a culpa convivem com a alegria espiritual, o princípio material do culto de um Deus encarnado faz-se verbo nas degradações e profanações do corpo.

Ainda que o conjunto de nomes que alimentam compêndios não signifique "a existência de uma verdadeira vida literária" que, segundo Antonio Candido, "só ocorrerá a partir do século XVIII" (CANDIDO, 2007, p. 21), pode-se falar em intensa vida cultural, pautada pela oralidade, pela comunhão e imposição litúrgica, pelas festas e procissões reinventadas nas cidades coloniais. O discurso popular, na pena letrada, aproxima literatura e perfomance cultural, revelando unidade no fragmento, sentidos ideológicos de uma sociedade em formação. Assim, ao aliar os campos abre-se a possibilidade de não olhar para essas manifestações com os padrões modernos da recepção literária, só entendida pela perspectiva do livro - como acontece em Formação da literatura brasileira.

Além dessa concepção, tem-se aquilo que Bakhtin define como cultura de fronteiras em sua análise do contexto de Rabelais e se aproxima da expressão utilizada por Turner ao longo de sua trajetória: betwixt and between - que poderia ser traduzida como entranhas (no que a palavra contém de ancestral e interior) e entre (limen, 'entrelugar', passagem). É nesse contexto que se insere esta análise da literatura e performance coloniais.

Em Dramas, campos e metáforas - ação simbólica na sociedade humana, Turner (2008) articula a proposição estrutural de Van Gennep para a ação ritual - preliminar, liminar e pós-liminar - e fundamenta sua teoria dos dramas sociais com foco na liminaridade e communitas. Com isso, concentra-se em momentos sociais em que a ação dos rituais provoca transições e transformações. Exatamente o que seria para Bakhtin a festa, o carnaval e eventos medievais que mobilizavam e congregavam as pessoas. As manifestações semânticas observadas por eles são justamente aquelas que abrem caminhos para novas realidades sociais, situações identitárias e artísticas: espetáculos, feiras, peregrinações, performances culturais etc. 
Assim, as análises literárias/culturais do povo na rua, do espetáculo como condição humana, dos discursos da praça e do grande corpo popular colonial implicam constante exercício de entender o mundo a partir de uma grande festa dialógica. Festa que, no contexto do catolicismo carnavalizado brasileiro, facultou situações religiosas (religantes) e provocava experiências sociais dramáticas e transformadoras. Essa visão, carregada de certo utopismo crítico, nunca impediu o reconhecimento de hierarquias violentas e monologismos axiológicos, mas permitiu olhar para o mundo com visão (teorein) mais celebrante.

Nesse sentido, uma análise que congrega literatura e performance pressupõe ramificações - oralidades, cenários, dramaturgias. O termo "leitor" ganha dimensão plural, visto que a relação autor/obra/público abriga uma multiplicidade de expectativas e variantes a partir da realização artística. Os estudos da performance provocam o reconhecimento de uma recepção interpretadora (BAKHTIN, 2003, p. 404-405), e a aproximação entre campos pode ser entendida como compreensão plena de relações dialógicas predominantes: "Esta liminaridade faculta experiências, pressente processos, modaliza funções (discursos realizados por grupos e indivíduos) e permite mapear estruturas" (SILVA JUNIOR, 2010).

Consciente de que ninguém disse nem dirá a última palavra, este exercício polifônico-teórico estabelece variantes dialógicas e monológicas de cada gênero, estilo e época. Com isso, as expressões são vistas por uma perspectiva plural - naquilo que iluminam das visões de seu tempo. As fronteiras polifônicas permitem assimilar os discursos em seus contextos, como assimilam e geram cronótopos, e facultam ainda o mapear da atuação de cada indivíduo, em cada papel, na enunciação liminar. Suas personae são interpretadas com variantes nos espaços públicos, espaços privados, espaços rituais etc. Ao discutir as relações predominantes no processo de colonização, a percepção de que os gêneros e modalidades discursivas se interpenetram é inevitável. Mesmo que sistemas culturais estabelecidos contenham o peso de valores burocráticos, nos rituais sagrados e seculares, e nas expressões artísticas residem valores expressivos e anseios transformadores: a questão não é a existência de uma verdadeira vida literária, mas de uma existência literária verdadeira.

Se os trovadores medievais entoavam seus versos com guitarras e cantavam romanceiros, realizando a implantação de novas línguas na poesia, visto que até o século XI predominavam o grego e o latim, o mesmo se deu no Brasil colônia com a "crônica musical" de Gregório de Matos e as cartas "anônimas" de Tomás António Gonzaga. De caráter festivo e aculturador, o teatro de Anchieta e a sermonística inventiva de Vieira deixaram aportar nestas terras, manifestações orais em eventos e rituais litúrgicos performáticos e sérios, e não menos carnavalizados, como bem mostrou Araújo: "na experiência brasileira o vocábulo 'público' quase nunca teve acepção política, mas de exibição, em que o 'sair em público', 'ir à rua', ganha forte acepção teatral, carnavalizando-se os atos coletivos (inclusive os religiosos) como forma e consolidação de papéis" (ARAúso, 2008, p. 26). 
Essas manifestações públicas e expressões coletivas, cada qual em seu campo, recriaram expressões e danças, versos e canções, estilos e gêneros. Discursos impressos no grande corpo da multidão.

O barroco no Brasil passou por um processo de transfiguração cultural, oferecendo leitura ativa do Novo Mundo e dos destinos do homem. Foi instrumento de doutrina e recomposição: o Paraíso revisitado, visões renovadoras do Éden, o Evangelho repaginado diante de um mundo a ser desvendado. O barroco nordestino metamorfoseou-se. Nas cidades mineiras, da fusão do classicismo árcade e acadêmico, ecoava, pelas paredes dos casarões, arquitetura católica que oferecia cruzes nos adros e telhados, e urbanização rococó composta de novos profetas e novas formas de talhar a cultura.

No campo das artes religiosas, produzidas nos primeiros momentos, o catolicismo carnavalizado se dá nos "autos" de Anchieta. Mesmo abrigando um processo violento de domínio sobre o outro (BOSI, 1996), é relevante que isso tenha acontecido com a utilização da poesia e do teatro, do sermão e da performance durante as missões e os festejos em dias de santo. O clamor do pecado e o sarcasmo devocional caminham juntos sob a aura de um cristianismo prático e econômico.

Nos autos, as marcas de oralidade, a fusão de línguas e linguagens englobam voz e corpo: "a nova representação do sagrado assim produzida já não era nem a teologia cristã nem a crença tupi, mas uma terceira esfera simbólica, uma espécie de mitologia paralela que só a situação brasileira tornara possível" (BOSI, 1996, p. 65). Essa terceira vertente simbólica é justamente aquilo que vimos tratando como catolicismo carnavalizado no contexto colonial. As fronteiras com códigos eruditos, semieruditos e a criação popular de cenas festivas. A transfiguração não ocorria apenas no campo da linguagem, mas exigia do jesuíta a capacidade de penetrar o imaginário do outro. Para tal, ele utilizava a música, as festas e a imaginária sacra dotada de signos e cores infinitamente marcantes (p. 25). Além disso, o verbo sagrado e os ecos classistas castelãos (aos moldes de Gil Vicente) eram tipicamente portugueses, mas as variantes prosódicas e melódicas eram tomadas de empréstimo ao tupi.

Na poesia, a herança trovadoresca mescla-se com a sonoridade e urgência de uma expressão tupi. Os sermões, mais frágeis, quando comparados com Vieira, noticiam, comungam, mas não alcançam uma poética discursiva. Nesse sentido, a maior contribuição de Anchieta teria acontecido no que ficou conhecido como teatro. Um reino de anjos e demônios banhado por um "Cristo que ressuscita individualmente e [um] Tupã que destrói em dimensões cósmicas" (p. 67).

Parafraseando Bakhtin, pode-se dizer que o padre utiliza-se do medo cósmico, herança medieval, para infundir no índio a noção de morte e de vida eterna cristãs. Tudo aquilo que era sobrenatural e anímico ao índio - o céu, as estrelas, o fogo, a força das águas dos rios e mares e os desastres naturais - ilustravam um medo que servia ao poder. Um poder que venceria tudo que fosse maligno e diabólico, e salvaria o convertido dos males post mortem. 
A tradução de práticas teatrais ocorre com palavras e corporificações. Anchieta organizava narrativas europeias em um enredo solto e voltado completamente para a veIha história de um cristianismo revisitado em dimensões díspares: os anjos têm asas de pássaros brasileiros, os demônios são índios de grupos em conflito com os Tupi, e os portugueses, historicamente, têm a noção cronológica abolida (foram salvos antes, serão salvos depois). Os autos compõem-se de partes trabalhadas para gerar o efeito no espectador e, ao mesmo tempo, inseri-lo no conjunto da festa religiosa e da missa, enquanto um conjunto de performances acontece no mesmo conjunto discursivo. Note-se, na partitura performática do Auto de São Lourenço, como se deu esse processo entre cultura popular e artes religiosas.

A peça foi representada no dia de São Lourenço (entre 1583 e 1586), onde hoje é a cidade de Niterói, e sua aura religiosa permitiu realizar o ritual litúrgico, louvar a Cristo e os santos, fazer exercícios de hagiografia e, ainda, levar os índios a performar numa espécie de palco, compactuando com a prática religiosa e levando os outros índios, espectadores, ao acordo inventivo:

Na Festa de São Lourenço congrega um elenco de personagens tão disparatadas, tão dilatadas no espaço e no tempo, quanto se possa desejar (...) A unidade dramática é das mais precárias, porém a de ordem pessoal adivinha-se qual seja. O tema de "São Lourenço", com as suas duas conotações, a geográfica e a histórica, a da vila e a do santo, chamou por contiguidade, por associação de ideias, todos os nomes que lhe eram correlatos no pensamento e na vivência de Anchieta, não importando se os fatos ocorreram há vinte ou há muitas centenas de anos (PRADO, 1993, p. 22-23).

A divisão da peça, nesta revisão de gênero, oferece dimensão plural para a ideia de auto teatral. Muitas partes e desdobramentos extrapolam o dramatúrgico e alcançam o campo da performance, do corpo e da voz:

Primeiro ato: representação performática do martírio de São Lourenço. Enquanto a expressão corporal acontece, os atores cantam em castellano um hino a Jesus crucificado e a São Lourenço queimado, que se sacrifica por seu Deus:

Por Jesus, meu salvador,/ que morre por minhas máculas,/ asso-me nestas grelhas,/ com fogo de seu amor. // Bom Jesus, quando te vejo/ na cruz, por mim chagado,/ eu, por ti, vivo queimado,/mil vezes morrer desejo. (ANCHIETA, 1999, p. 3)

Os símbolos agregam múltiplas cargas semânticas: a iminência do fogo, a imagem da cruz, o sangue derramado, tudo em nome do pai. O fogo metafórico do amor de Deus pelos homens presentifica-se na encenação do sacrifício do santo do dia.

Segundo ato: ações dramáticas intercaladas de prédicas e música religiosa. Presença simbólica de tríades. a) diabos, organizados em hierarquia católica, que querem destruir a aldeia de São Lourenço: Guaixará (rei dos diabos) e seus servos Aimbirê e Saravaia; b) cristãos guerreiros para defender e salvar esses inimigos: São Lourenço (queimado), São Sebastião (oportunamente flechado) e um anjo. O mal, a ser batido, nesse ato, são as práticas culturais indígenas tapuia e tupi: a cauinagem, a dança, os enfeites e pinturas, fumos e feitiços, a antropofagia, a mancebia, a alcovitice e a prostituição 
(p. 42-58). Uma performance trazendo um conjunto de regras, uma teatralização do conflito entre culturas e o medo dos índios diante dos santos triunfantes que chegam, exemplarmente, a açoitar os índios-diabos. $\mathrm{O}$ anjo reafirma o que disseram e fizeram os santos com uma prática - parte musical da missa: "Alegrai-vos, meus filhos, por minha causa; Eis que aqui estou para vos libertar" (ANCHIETA, 1999, p. 51).

Terceiro ato: um teatro hagiográfico e histórico presentifica as primeiras bataIhas do cristianismo em nome de sua afirmação. Mais uma vez Anchieta duplica imagens e utiliza-se de um auto para anunciar uma nova Cruzada: dois servos demônios, convertidos no ato anterior torturam Décio e Valeriano, responsáveis pela morte de São Lourenço. A performance cultural conta a história do suplício com imagens que alimentam o medo cósmico e que representam força e sacrifício - inerente a todo cristão em nome da religião. $\mathrm{O}$ dramaturgo e combatente jesuíta vence os romanos não convertidos e os tapuia rebeldes. Nesse ato, uma das mais inventivas criações de Anchieta, Aimbirê (pássaro grande; semelhante ao karaibebé, profeta voador de sua lírica) ajuda os santos contra os combatentes romanos - derrotados historicamente e na peça/performance sacra.

Quarto ato: nova tríade: Anjo, o Temor de Deus e o Amor de Deus mandam suas mensagens para os índios (público-alvo de Anchieta): eles devem amar e temer a Deus que por eles tudo sacrificou. $\mathrm{O}$ corpo do santo que morre e se torna sagrado é retalhado (mas não comido) e colocado em uma tumba, como exige o preceito cristão. O Temor cósmico ameaça todo aquele que se coloca contra a cruz. Se o segundo e terceiro ato demonstraram isso por meio de imagens de luta, nesse momento os "tipos", ao estilo de Gil Vicente, encaminham o diálogo moralista. Cada um traz seu recado: o Anjo trata do martírio, o Temor do (fogo do) inferno, e o Amor da devoção.

Quinto ato: um jogral de 12 crianças tupi, canta na procissão de São Lourenço. Festa, missa e performance católico-carnavalizada se fundem para a catequese dos índios. Elementos cristãos congregam as práticas indígenas e atendem questões políticas urgentes: torná-los católicos pelo amor da cruz e pela força do/de trabalho.

Os contrastes internos da colônia dialogam com o esforço de penetração no imaginário do outro: o colonialismo surge como sistema cultural. Esse Abarebebé (padre santo voador) é o signo do primeiro intelectual atuante (Companhia de Jesus no Brasil) e representa o letrado buscando formas poéticas e performáticas de articular e de manipular os elementos do imaginário ocidental - traduzidos na colônia.

No autos de conversão/catequese Anchieta colocava o discurso cristão na boca e no corpo do outro. Com isso, uma eficiência religiosa, com certo didatismo autoritário, atendia certo processo de humanização. Na mesma festa, uma performance católico-carnavalizada agregava uma poética oral e imagens religiosos, com elementos anímicos de uma rapsódia, pois não oferecia unidade de ação e de tempo lineares: cenas nativas, lutas por território (contra franceses), jogos diabólicos dos Tapuia (a favor dos franceses), louvores, conversão, música, pantomima e diversão.

Nesse universo que alia procissão e teatralização, as estratégias narrativas representam um mau selvagem e os pecados, e o éthos indígena (identidade, sociedade, cul- 
tura) permitindo a Anchieta forjar uma mitologia paralela colonial e uma demonização dos ritos indígenas - isso significa suplantá-los.

Nesse sentido, com esse conjunto de detalhes parece mais viável designar a obra de Anchieta como uma performance híbrida que articula uma pluralidade de gêneros entre dramas, campos e metáforas, todos diluídos em um objetivo maior, que é a festa de louvor em honra de anjos, santos e um Deus encarnado, crucificado e individualizado.

Padre António Vieira, por sua vez, articulou cenas e ideias no contexto do catolicismo carnavalizado em outra modalidade discursiva: o sermão. No século XVII, foi importante orador a serviço da evangelização e da Coroa portuguesa. Intervenções autoconscientes sobre a arte de pregar permitiram que outras vozes ecoassem de seus sermões orais, escritos e compilados.

Nessas fendas, a princípio monológicas, que oferecem índices dialógicos do período colonial, a autoconsciência possibilita reflexões sobre o gênero eclesiástico. Com isso, outros gêneros e manifestações populares, tais como o teatro, a oratória e o carnaval, são discutidos pelo jesuíta. Cabe à crítica interpretadora captar essas vozes e traçar um novo panorama da cultura brasileira na perspectiva da performance.

O processo de iluminação recíproca das línguas e das culturas foi intensamente apreendido por Vieira. Ele discutia a respeito de tudo que percebia como mudança, lançando novas noções, repetindo algumas opiniões e 'performando' do alto do púlpito o choque de mentalidades de um Ocidente em expansão. Diante das tensões coloniais, o púlpito, aliás, apresenta-se como privilegiado locus dramaticus (ZUMTHOR, 2001) para enunciar ideias sobre o homem, 're-visões' do paraíso, a conversão dos gentios. Tudo isso aliado a violenta prática de exploração, dominação e expansões territoriais.

A partir dos sermões compilados, com projeto editorial do próprio padre, é possível extrapolar o campo religioso - sem o perder de vista. Isso significa dizer que não consideramos Vieira um escritor no sentido adquirido a partir do século XVIII, mas um pregador que desempenhava dramas sociais numa espécie de performance que conjugava imagens cristãs, epifrásicas e adverbiais, da vocalidade, e a corporalidade de um homem consciente da tradição oratória e do teatro romano, principalmente de Sêneca (HOLANDA, 1985, p. 226), sempre citados e apontados em dezenas de sermões. Referências que permitem enxergar, segundo Freire, as fronteiras dos tempos na produção discursiva oral que, por sua vez, superava a produção impressa do período colonial:

Poderia o jesuíta luso-brasileiro apoiar-se no que disseram esses humanistas a fim de abrandar, quando necessário, o que dissera da inaptidão dos nossos sentidos para alcançar o incorpóreo e o eterno. Poderia ainda, e com maior coerência, segundo a milícia em que se alistara, amparar-se no próprio Santo Inácio e em exemplos e ditos de alguns inacianos. Pois não fora um dos esteios do método propugnado pelo fundador da Companhia de Jesus, o recurso aos sentidos, o "traer los cinco sentidos", e, em particular, às imagens visuais nos exercícios religiosos? Já no primeiro exercício requeria, após a oração preparatória, aquela célebre "composição de lugar, vendo o lugar" (FREIRE, 2000, p. 224). 
É necessário, portanto, principalmente no que diz respeito ao processo de colonização, entender voz e performance como as principais ferramentas de 'poeticidade' e praticidade realista. O homem domina pelo corpo, e o literário é impresso no corpo da multidão. Nesse sentido, as ações sociais oferecem dramas sociais e metáforas em situações de performance. Na representação vieiriana é possível captar elementos instáveis e cotidianos e formas do espetáculo numa percepção barroca colonial de mundo. A noção de catolicismo carnavalizado auxilia nessa visão da performance, pois amplia o entendimento do "literário" e do espetáculo na festa e na celebração. O momento de enunciação do sermão é sempre liminar - afinal, liga-se a um conjunto de ações que provocam transformações. Segundo Victor Turner, as atividades liminares envolvem ações festivas, simbólicas e extracotidianas e são "campos" em que "paradigmas são formulados, estabelecidos e entram em conflito" (TURNER, 2008, p. 15). A partir dos sermões vieirianos, com os resquícios das performances que o gênero encerra, busca-se o “(...) fator da 'consciência' que deveria levar (...) a um estudo intensivo de culturas letradas complexas, nas quais as mais articuladas vozes conscientes de valores são os poetas, filósofos, dramaturgos, romancistas, pintores, 'liminoides' e afins (TURNER, 2008, p. 15).

A vida pública de Vieira foi dramática, sendo assim possível compreendê-la como um drama social com muitos conflitos, situações intensas e articuladas discursivamente por ele nos bastidores e nos púlpitos.

No campo das letras e das vozes coloniais a arte foi forte instrumento de dominação e aproximação linguístico-cultural. Com padre Vieira, temos um choque de mentalidades, e as tensões de uma época apaixonada entram em conflito com a herança clássica e religiosa (PALACIN, 1986). No contexto de um catolicismo carnavalizado brasileiro, seus escritos retratam suas meditações, os traços que a vida impõe a um pensador e sua realidade vivida, plena de contraditórias ações sociais. De ordem religiosa, política, cultural, o barroco no Brasil reconfigura-se nas suas performances literárias plenas de marcas e vozes desse período.

Exímio pregador, desde o princípio, Vieira chamou atenção por seu estilo sermonístico, pela prosódia abrasileirada e pela capacidade de aproximar-se de cada público, escolhendo imagens, palavras e temas que "incomodavam" e provocavam: "Compleição de artista hábil em penetrar a vida secreta do vocábulo, erudição vasta, magnetismo pessoal, talento de atrair e dominar tudo que dele podia fazer um orador raro e triunfador" (ARAúso, 2008, p. 76).

Em situação de perfomance, o padre dialogava com os eventos de seu tempo e utilizava o sermão até para discutir a arte do bem pregar: "os ouvintes não lhe pediam emoções vivas; o gozo provinha-lhes da novidade dos conceitos e da surpresa da combinação verbal (ARAÚjo 2008, p. 76). Sua performance do sacramento aproximava corpo e voz: "O pregar, que é falar, faz-se com a boca; o pregar que é semear, faz-se com a mão" (VIEIRA, 1959, p. 15). Uma vez que o verbo divino caracteriza-se pela ação, elabora uma teoria da performance do pregador no próprio ato da pregação: “A razão disto, é porque as palavras ouvem-se, as obras veem-se; as palavras entram pelos ouvidos, as obras en- 
tram pelos olhos, e a nossa alma rende-se muito mais pelos olhos que pelos ouvidos" (...) Sabem padres pregadores, por que fazem pouco abalo os nossos sermões? Porque não pregamos aos olhos, pregamos aos ouvidos" (VIEIRA, 1959, p. 15-16).

Consciente de que o púlpito era um espaço para "fazer figura" (encenar), suas performances "atraíam o público mais do que as comédias e, a ouvir os oradores de fama concorriam o rei e a corte" (ARAúso, 2008, p. 76). O "Sermão da Sexagésima" ainda discute o "literário" e a cena colonial entre o púlpito e o tablado:

os ouvintes vem à pregação como à comédia; e há pregadores que vêm ao púlpito como comediantes (...) Não cuideis que encareço em chamar comédia a muitas pregações das que hoje se usam. Tomara ter aqui as comédias de Plauto, de Terêncio, de Séneca, e veríeis se não acháveis nelas muitos desenganos da vida e vaidade do mundo (...) Grande miséria por certo, que se achem maiores documentos para a vida nos versos de um poeta profano e gentio, que nas pregações de um orador cristão, e muitas vezes, sobre cristão, religioso!" (VIEIRA, 1959, p. 33).

Além do elogio aos dramaturgos clássicos por seu caráter moralista, Vieira demonstra profundo conhecimento deles e os evoca, diante da fraca performance dos pregadores de seu tempo. Os elementos de uma poética barroca em Portugal e a cena teatral analisada em seu contexto tornam-se em sua retórica metalinguística o performativo para demarca a ação.

No "Sermão da Primeira Dominga do Advento", por exemplo, o verbo divino transforma-se em advérbio sermonístico. Sua consciência do espetáculo é construída a partir de jogos de imagens: "Considerai-me o mundo desde seus princípios, e vê-lo-eis sempre, como nova figura no teatro, aparecendo e desaparecendo juntamente, porque sempre está passando" (VIEIRA, 1959, p. 112). A primeira cena desse teatro foi o Paraíso Terreal, e seu theatrum mundi é construído com reflexões sobre a palavra, sobre o fazer figura e a perda e recuperação iminente desse locus. No mesmo sermão ele renova essa discussão com uma breve história do espetáculo greco-romano: “(...) os jogos e espetáculos públicos que os homens inventaram a título de passatempo, como se o mesmo tempo não passara mais velozmente que tudo quanto passa. Uns jogos foram os Circenses, outros os Dionísios, outros os Juvenais, outros os Nemeus, outros os Maratónios, todos cheios de diferentes divertimentos" (p. 116).

Nesse conjunto de cenas e breve história da humanidade contada a partir das festas gentis, encontramos ainda o carnaval no contexto católico. No "Sermão das Quarenta Horas", tem-se um retrato dessa celebração no interior da igreja, com padres e fiéis festejando o entrudo. Embora a intenção seja 'monologizante', colhe-se, de uma perspectiva plural, o que o discurso do intelectual letrado oferece no que diz respeito aos aspectos da cultura popular do período colonial.

Segundo Vieira, o entrudo teria nascido, parodicamente, do Sanctus Introitus, ou seja, as 40 horas que antecedem a Quaresma e que deveriam ser dedicadas à oração e não à festa da carne. Horas sagradas que eram (mas não deveriam!) ser festejadas dentro 
da igreja: “(...) os padres da Companhia, porque não tinham a quem festejar, festejavam o Santo Entrudo (VIEIRA, 1959, p. 139).

As exigências da ordem são confrontadas pelas práticas cotidianas e pecaminosas - posto que humanas. Diante da incompatibilidade do sistema colonial e o atos do governo, perante os votos de liberdade e a existência legal da escravatura, imposta pela economia, o padre conjuga o rito diário com a estabilidade social necessária para a Igreja e para a Coroa. Seus sermões cobram implacavelmente as ações no dia a dia e articulam no âmbito da performance do sacramento:

as dolorosas contradições, tão patentes na obra de Vieira, entre os altos ideais declarados - na ordem política, social, religiosa - e as mesquinhas contingências da vida social, aceitas como inevitáveis, tornam-se um dos exemplos vivos dessa tensão de luzes e sombras que constitui a procura insatisfeita do barroCo (PALACIN, 1986, p. 11).

Em resumo, uma vez que se reconheça esse diálogo entre literatura e performance, a crítica literária consegue examinar, por nova perspectiva, os fenômenos culturais. Os símbolos, a vocalidade e corporalidade podem não só refletir aspectos sociais, como também contribuir para sua recriação. Em Anchieta e Vieira o theatrum sacrum barroco ganha contornos de performance carnavalizada - uma espécie de lugosi sacrae. Fundando a história no Novo Mundo trazem o contingente temporal do presente. Nessa presentificação reside o elemento performático: uma representação para um plateia em determinados espaço e tempo bem definidos.

Assim sendo, a letra e a voz coloniais pressupõem a fronteira como liberdade na ação e no discurso. Mesmo que seja uma liberdade que exige disciplina, paradoxo clássico, e que apareça justamente nos discursos artísticos presos a moldes, cânones, instituições e tradições, no discurso da festa colonial, no movimento do grande corpo carnavalizado, nessa representação insubstituível, única e coletiva, reside a unidade interna de elementos heterogêneos. Nesses mundos criados discursivamente, pertencentes ao mundo, revela-se uma dialógica da colonização.

Articular literatura e performance é um convite a repensar a antiga lugosi - e recontar a história literária de novas perspectivas, respeitando as formas discursivas de cada época e não forçando leituras com ferramentas posteriores. Entendida aqui no sentido de 'performar' e não somente de falar, a performance do sacramento apresenta o infinito na Terra. Assim, a literatura colonial é relida, em seus rituais de confronto entre autores e espectadores. $\mathrm{O}$ efêmero da oralidade, da não sistematização, pressupõe imagens fragmentadas de um novo mundo em escritos também fragmentados. Ao captar os resquícios do cotidiano, os dramas, campos e metáforas, essa tradição crítica, consolidada por Bakhtin, Turner e Zumthor, oferece um exercício de reavaliação desse longo período cultural, violento e carnavalizado, como nossa Idade Primeira - obscura e evanescente, ainda com muitas pistas a seguir e ecos a ouvir. 


\section{REFERÊNCIAS BIBLIOGRÁFICAS}

ANCHIETA, José de. Teatro. São Paulo: Martins Fontes, 1999.

ARAÚJO, Emanuel. O teatro dos vícios: transgressão e transigência na sociedade urbana colonial. Rio de Janeiro: José Olympio Editora, 2008.

BAKHTIN, Mikhail. Cultura popular na Idade Média e no Renascimento: o contexto de François Rabelais. São Paulo: Annablume/Hucitec, 2002.

. Estética da criação verbal. Trad. Paulo Bezerra. São Paulo: Martins Fontes, 2003.

BOSI, Alfredo. Dialética da colonização. São Paulo: Companhia das Letras, 1996.

CANDIDO, Antonio. Formação da literatura brasileira. Belo Horizonte: Ed. Itatiaia, 1993. . Iniciação à literatura brasileira. Rio de Janeiro: Ed. Ouro sobre Azul, 2007.

FREIRE, Gilberto. Casa Grande \& Senzala. Rio de Janeiro: Record, 2000.

HOLANDA, Sérgio Buarque de. Visão do Paraíso: os motivos edênicos no descobrimento e colonização do Brasil. São Paulo: Ed. Nacional, 1985.

PICCHIO, Luciana S. História do Teatro Português. Lisboa: Portugalia Editora, 1964.

PRADO, Décio de Almeida. Teatro de Anchieta a Alencar. São Paulo: Perspectiva, 1993.

PALACIN, Padre Luís. Sociedade colonial. Goiânia: Ed. UFG, 1981.

. Vieira e a visão trágica do barroco. São Paulo: Hucitec/Pró-Memória, 1986.

SILVA JUNIOR. Literatura e cultura: o complexo problema do dialogismo e a metodologia do sistema crítico polifônico de Mikhail Bakhtin. In: Círculo - Rodas de conversa bakhtiniana 2010 - Caderno de textos e anotações. São Carlos: Pedro \& João Editores, 2010.

TURNER, Victor. Dramas, campos e metáforas: ação simbólica na sociedade humana. Niterói: Eduff, 2008.

VIEIRA, António. Sermões. In: Obra Completa. Porto: Lello \& Irmão Editores, 1959, v. I, tomos l e II.

ZUMTHOR, Paul. A letra e a voz: a "literatura medieval". São Paulo: Companhia das Letras, 2001.

Augusto Rodrigues da Silva Junior é professor adjunto de literatura brasileira do Departamento de Teoria Literária e Literaturas (TEL/UnB) e faz parte do Programa de Pós-Graduação em Literatura no Instituto de Letras da Universidade de Brasília. É pesquisador do Laboratório Transdisciplinar dos Estudos sobre a Performance (SOL/UnB) e desenvolve pesquisa com a festa do divino Espírito Santo no território quilombola Kalunga e com a procissão do fogaréu na cidade de Goiás. 